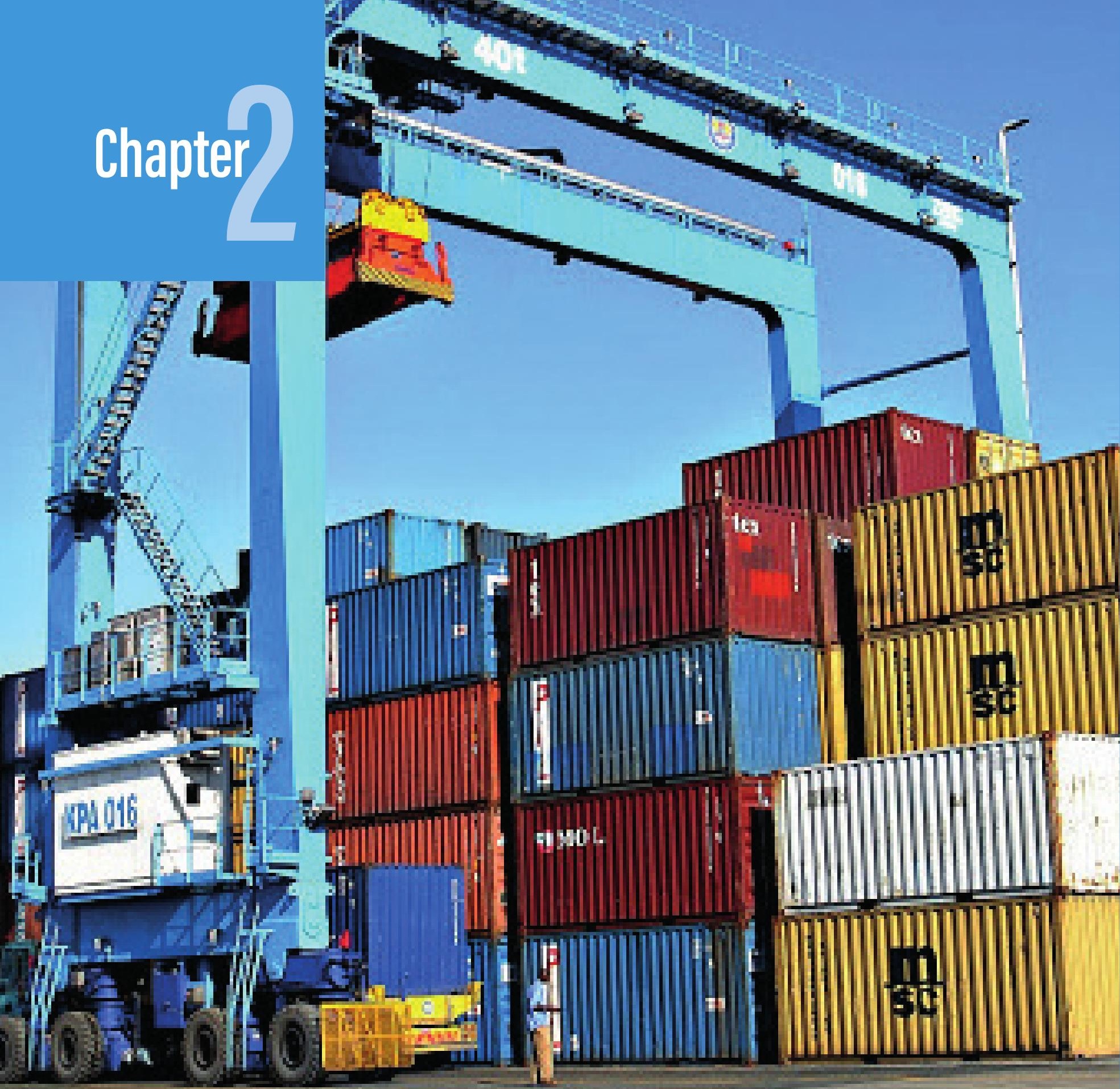

\title{
Africa in Global Agricultural Trade
}

Sunday Pierre Odjo and Chahir Zaki 


\section{Introduction}

Africa represented around 11 percent of world agricultural GDP and 4 percent of world agricultural exports in 2018 (World Bank 2020). At the same time, the agriculture sector remains an important source of livelihood for more than half of the African population. Yet, the region still faces numerous impediments that affect its trade performance. Despite implementation of several trade agreements including the regional economic communities (RECs) intended to boost trade, Africa's exports have not improved significantly.

This poor trade performance can be explained by a combination of supply-side and demand-side factors. On the supply side, the agriculture sector suffers from low productivity because of the limited use of irrigation and dependence on rainfed agriculture (Moyo 2016; Olayide et al. 2016). Second, at the budget level, public spending allocated to agriculture is minor, which affects investment and infrastructure in this sector, especially for farm equipment, machinery, and such. Third, insufficient use of modern technologies affects the sector's performance (Boniphace et al. 2015; Pindiriri 2018).

On the demand side, African exporters face several trade barriers (both tariffs and nontariff measures) that affect their penetration in developed and emerging markets (Disdier et al. 2008; Gelan and Omore 2014; Liu et al. 2019). Moreover, African products are not sufficiently competitive, as they do not meet the quality standards of world markets (World Bank 2015). As a consequence of all these handicaps, the agriculture sector continues to underperform in general and at the export level in particular.

The 2019 Africa Agriculture Trade Monitor (Chapter 2) showed that, although Africa has a trade deficit in agriculture, this deficit has been significantly reduced since 2012 and Africa's share of global agricultural GDP has been steadily increasing since 1995. Moreover, Africa has comparative advantages in traditional agricultural products that are either raw or unprocessed such as cocoa, coffee, cotton, fish, fruits, legumes, and tea. An important finding is that there is a high concentration of exports in a relatively small number of products, which are, again, raw or semiprocessed. Finally, it showed that Africa performs poorly in terms of participation in world trade, whether intra- or extraregional, as a result of supply- and demand-side constraints and nontariff barriers, especially administrative barriers.

Against this background, the objective of this chapter is to provide an overview of Africa's trade structure and trade policy. We first analyze recent performance in different markets and identify changes in the composition and direction of trade. Second, we examine both tariffs and nontariff measures faced by African agricultural exporters, using several sources of data for trade barriers.

Our main findings show that, while agricultural productivity is low, the European Union remains the primary destination for agricultural exports, although its share is constantly decreasing. At the product level, the top 10 agricultural export products represent 39 percent of Africa's agricultural exports and include sesame seeds, black tea, cocoa paste, and fresh grapes. In terms of trade barriers, despite low tariffs faced by African economies, they are facing several nontariff measures (NTMs) ranging from sanitary and phytosanitary measures to conformity assessment and domestic support in other countries. Indeed, and in particular for agriculture products, unfair competition resulting from the domestic support in other countries affects the competitiveness of African countries' exports. 
The following section provides a general overview of the agriculture sector in Africa in terms of value-added, employment, and trade performance. The next section examines trade policies facing African countries in both developed and emerging markets, and the final section of this chapter offers some conclusions.

\section{Trends in agricultural trade in Africa}

\section{General trends}

Despite its comparative advantage in several agricultural products, Africa's share in total exports at the world level is relatively low when compared to other regions with a similar level of development. Africa's share in world agricultural exports averaged 4.2 percent between 2003 and 2018, while the Asia-Pacific developing region averaged 16.9 percent and Latin America and the Caribbean (LAC) averaged 15.6 percent over the same period (see Figure 2.1).

Figure 2.1 Share in total world agricultural exports, by region

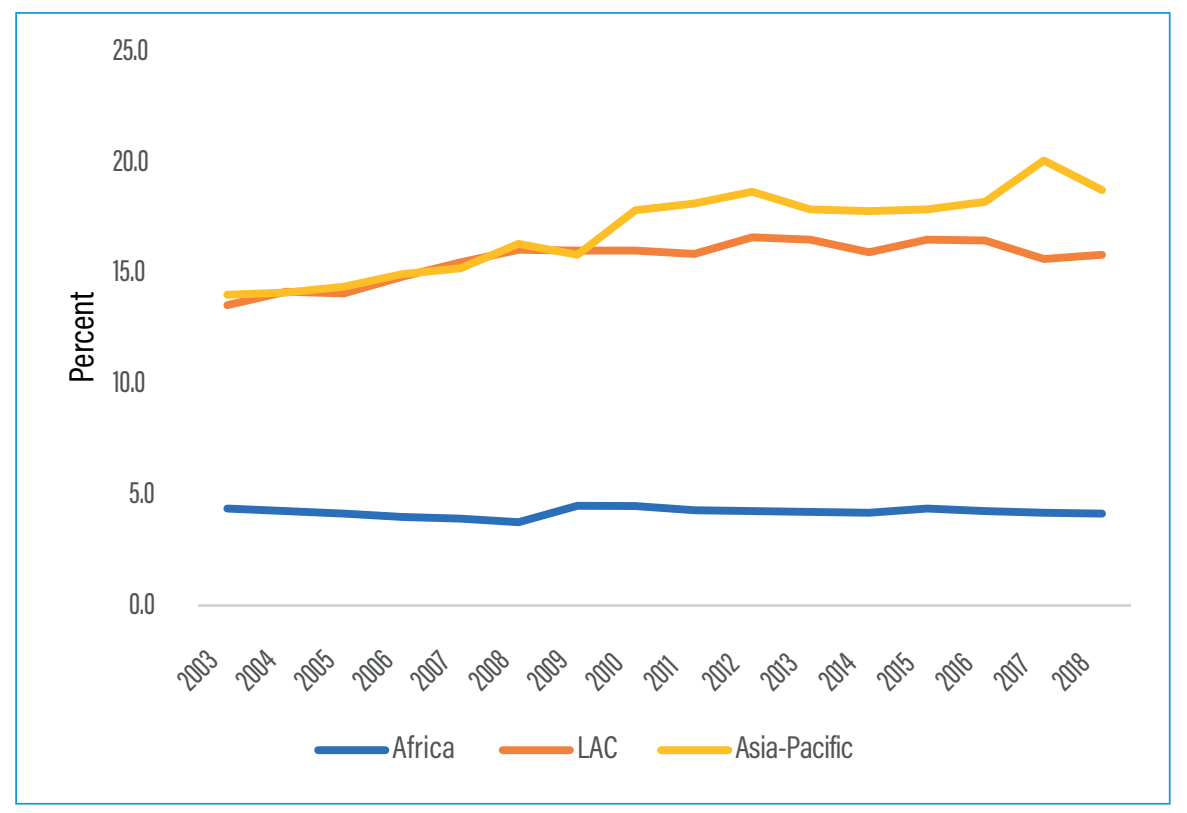

Source: 2020 AATM database.

Such a weak performance becomes more evident when the share of Africa's agricultural exports is compared to its share in the world's agricultural value-added. Figure 2.2a shows that, on average, Africa represents 10.2 percent of the world's agricultural GDP (and Africa's total GDP represents 2.7 percent of the world's GDP, see Figure 2.2b), whereas LAC and Asia-Pacific's shares of world agricultural GDP are 9.5 percent and 54.9 percent respectively ( 7.6 percent and 29.5 percent of total GDP). Hence, in terms of shares, Africa is doing slightly better in production than exports. This can be explained by several factors, including large domestic demand, lack of competitiveness, high tariffs, and numerous NTMs in different destinations. Some of these issues will be explored in this report. 
Figure 2.2a Share in world's agricultural GDP, by region

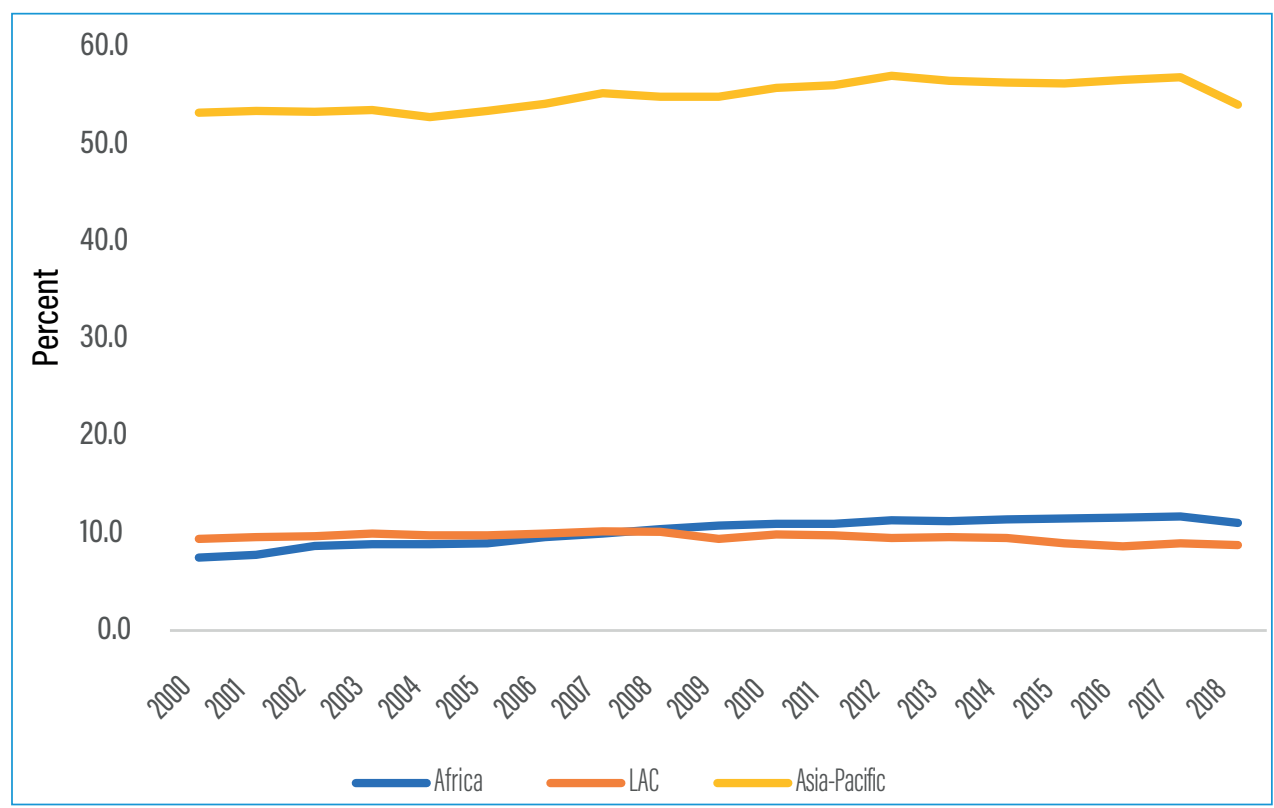

Figure 2.2b Share in world's GDP, by region

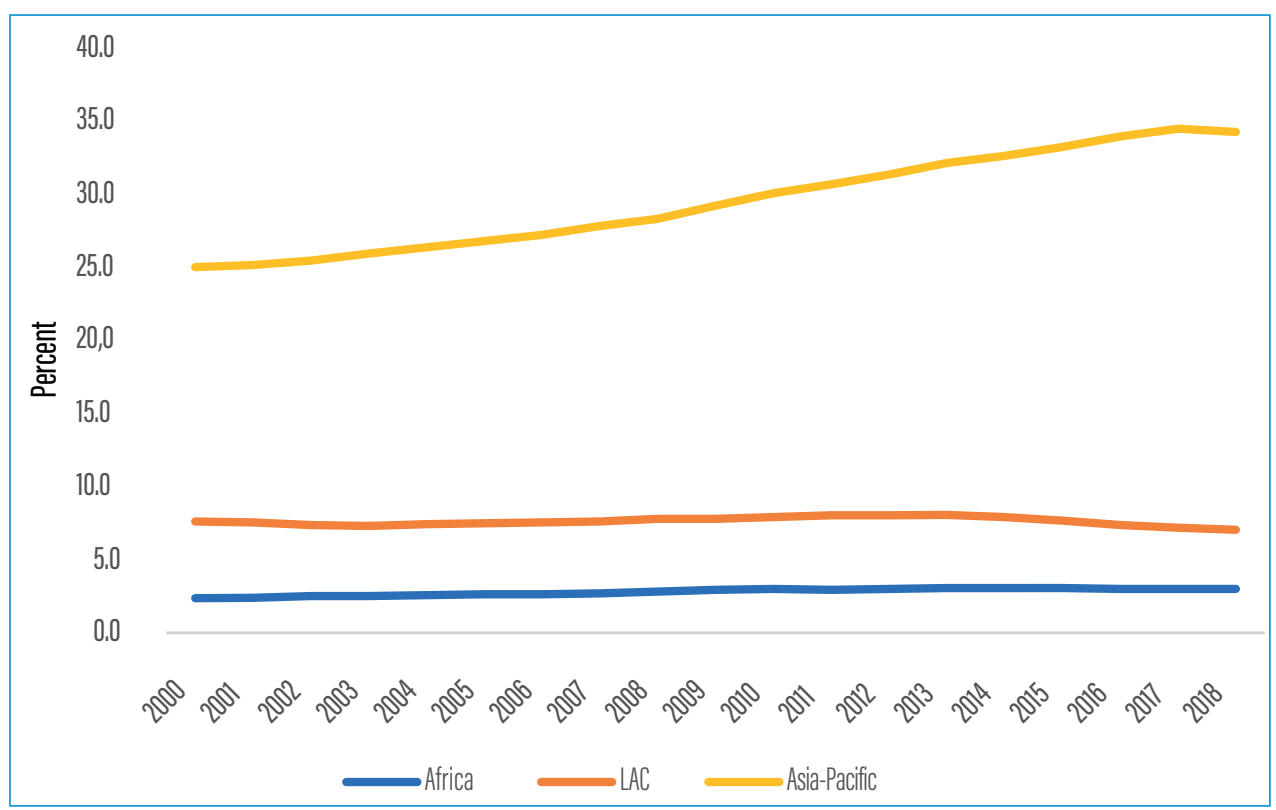

Source: World Development Indicators.

Note: Figures are calculated using 2010 constant US dollars.

One of the reasons underlying the weak performance of Africa in the agriculture sector on the supply side is the low labor productivity in this sector. Figure 2.3a shows that, on average, while this sector accounts for 59 percent of total employment in Africa (and 36 percent in Asia-Pacific and 17 percent in LAC), its productivity (calculated as value-added per worker) does not exceed 50 percent of Asia's productivity or 20 percent of LAC's (Figure 2.3b). Furthermore, it is important to note that, while Africa's productivity stagnated over the whole period, LAC and Asia experienced increases. 
Figure 2.3a Employment in the agriculture sector

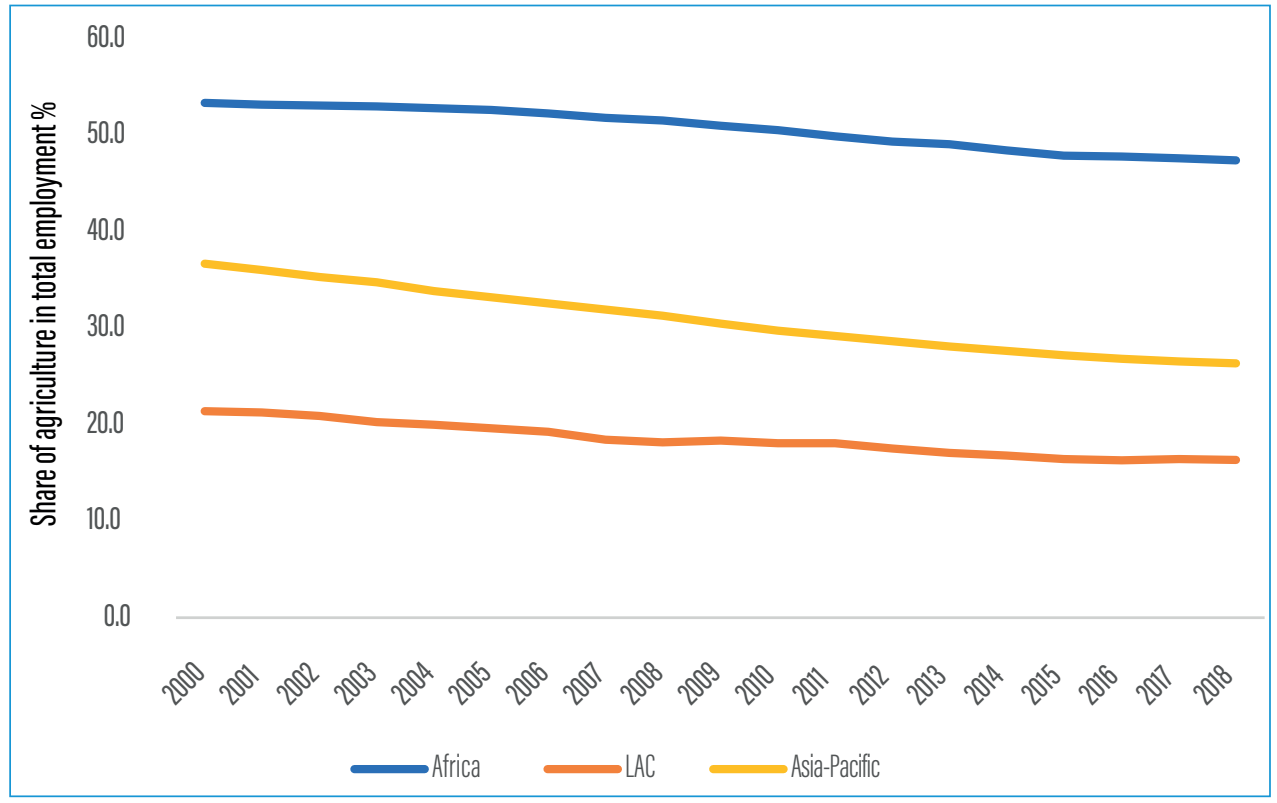

Figure 2.3b Productivity in the agriculture sector

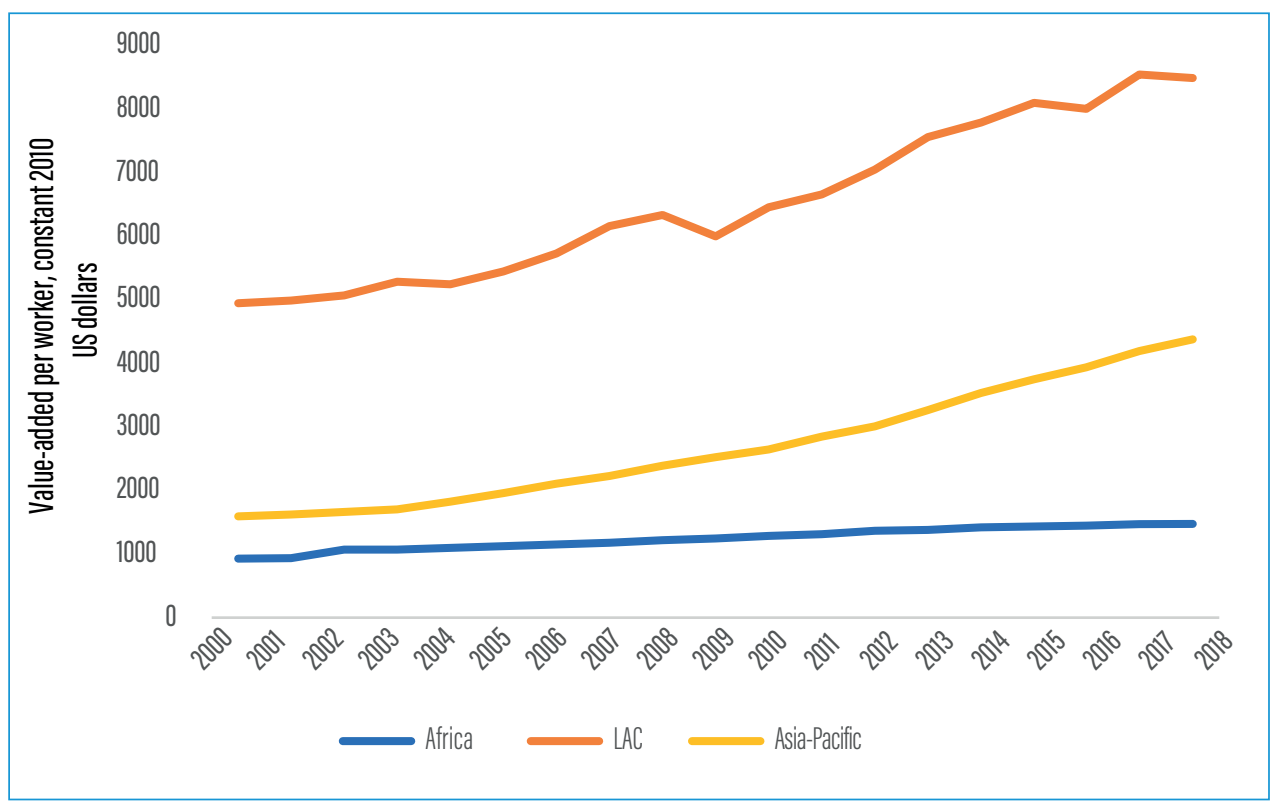

Source: World Development Indicators.

In a nutshell, Africa has low productivity in the agriculture sector and a trivial share in world agricultural exports compared to other emerging regions. Yet, this result hides a lot of heterogeneity at the level of the products exported by African countries and the level of markets served by them. Therefore, the next section will examine the main destinations and products exported by African countries.

21

Africa Agriculture Trade Monitor / 2020 Report 


\section{Where do Africa's agricultural exports go?}

Africa's low share of world agricultural exports between 2003 and 2018 hides an upward trend in the value of its agricultural exports. Figure 2.4 depicts a sustained growth pace in export value that was interrupted only in 2015-2016. The figure highlights the evolution of the shares of major destinations of African agricultural exports. The European Union (EU) has remained the main destination, though its share has steadily decreased, with on average 45 percent in 2005-2007 and 36 percent in 2016-2018, with raw products ranked first. The United States accounts for 5 percent of African agricultural exports, with on average no significant change since 2003. IntraAfrica destinations have almost invariably accounted for 20 percent of African agricultural exports.

In contrast, Brazil, Russia, India, and China (BRIC) have increased their combined share from 10 percent in 2005-2007 to 14 percent in 2016-2018. Similarly, the share of Africa's exports to other world regions has increased significantly, from 20 percent in 2005-2007 to 25 percent in 2016-2018. Thus, Figure 2.4 shows that African exporters are diversifying away from EU market destinations toward emerging markets of BRIC and elsewhere outside the developing world (right axis). Figure 2.5 shows that, in value terms, EU imports of Africa's agricultural products have experienced a sustained increasing trend, despite the decrease in shares observed in Figure 2.4 (right axis). Similarly, Figure 2.5 indicates that US agricultural imports from Africa have been increasing, though the US share of Africa's export market has not significantly changed. Therefore, the diversification of Africa's agricultural exports mostly consists of market expansion into emerging and fastergrowing countries while sustaining exports to traditional markets in advanced economies.

Figure 2.4 Africa's agricultural exports value and major destinations, 2003-2018

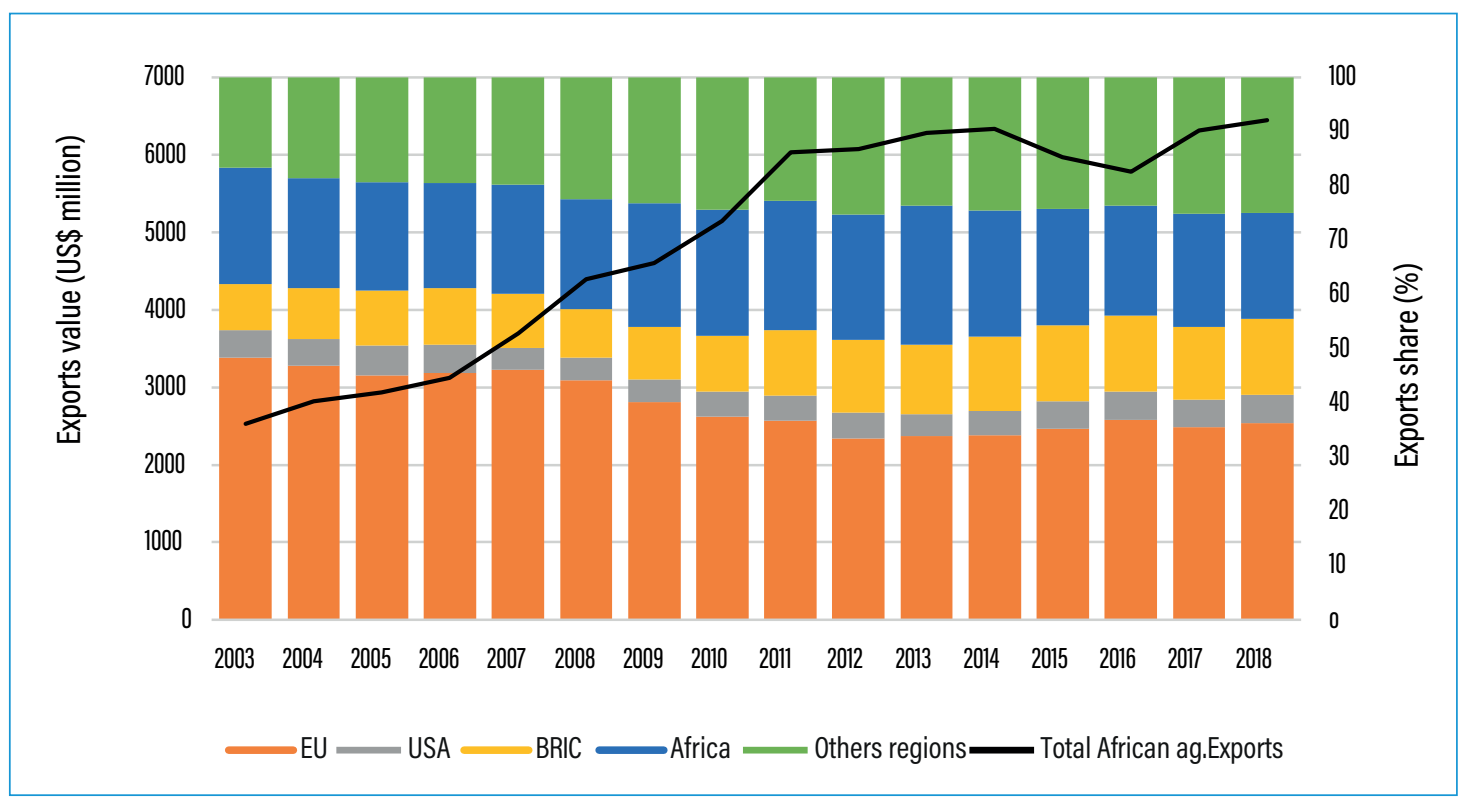

Source: 2020 AATM database. 
Figure 2.5 Trends in Africa's agricultural exports to major destination markets

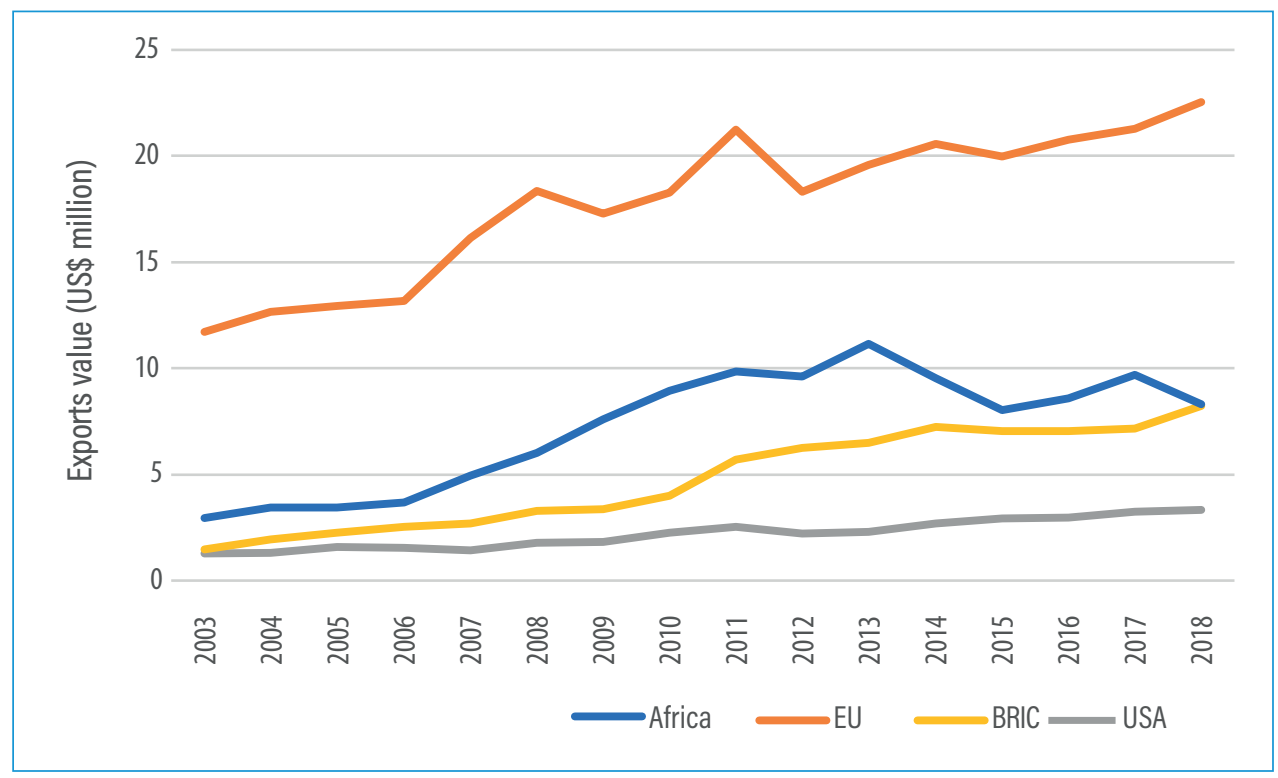

Source: 2020 AATM database.

We now turn to scrutinize which countries of the above five world regions are the top destinations for African exporters. Table 2.1 presents the leading destinations for Africa's agricultural exports in ascending order of their ranks in 2016-2018 along with their ranks in 2005-2007 and their shares in total agricultural exports in both periods. As for most economies in the world, EU countries, the United States, and China are the leading export (as well as import) partners of African economies in terms of value. The Netherlands, France, the United States, Germany, and China are the top five destinations and together account for 30 percent of Africa's agricultural exports in 2016-2018, almost the same average share as in 2005-2007.

It is worth noting that between the two periods these five countries have displaced the United Kingdom, which ranked first in 2005-2007 and sixth in 2016-2018. China has progressed by two places, from number 7 to 5 , and India has moved from 14 to 7 , moving past seven countries, namely Japan, Saudi Arabia, South Africa, the Russian Federation, Spain, Italy, and Belgium. No African country is among the top 10, and South Africa, which ranked as number 11 in 2005-2007, has fallen to 15 in 2016-2018. Most interestingly, Viet Nam has moved up in the rankings from 69 to 12. Also, Kenya, Malaysia, and the United Arab Emirates have recently joined the top 20 destinations for Africa's agricultural exports.

Africa's 20 top trade partners account together for 65 percent of the continent's total agricultural exports in both reference periods. Interestingly, these partners account for a slightly lower share of world agricultural export destinations. As can be seen in Table 2.1, they were the destinations for 61 percent and 58 percent of global agricultural exports in 2005-2007 and 2016-2018, respectively. Viet Nam, India, China, and the United Arab Emirates have increased their shares in Africa's agricultural export markets most significantly between the two periods. For instance, Viet Nam's importance as a destination for African exporters has increased tremendously - from 0.3 percent to 2.5 percent of the continent's exports. The increased share of these countries is mirrored by the declining share of other partners including remarkably the United Kingdom, Italy, France, Germany, and Japan. For example, the UK share in Africa's exports decreased from 9.0 percent to 4.3 percent.

It is worth noting that almost all partners that expanded or reduced their importance as destinations for Africa's exports likewise expanded or reduced their share of world the United States, Saudi 
Arabia, the Russian Federation, and Spain are the exceptions. Russia has increased its share of Africa's export market but decreased its share of world exports. The shares of the Netherlands, the United States, Saudi Arabia, and Spain in world exports have remained unchanged while their share in Africa's exports contracted.

In sum, this analysis of the leading partners for African exporters shed light on the decreasing importance of the EU and the increasing weight of BRIC and "other world regions" as destinations for Africa's agricultural exports. This trend largely reflects the faster economic and demographic growth in emerging countries compared with advanced economies over the last few decades. In the next section, we investigate the changes in Africa's list of most exported products.

Table 2.1 List of top 20 destinations of Africa's agricultural exports in 2005-2007 and 2016-2018

\begin{tabular}{|c|c|c|c|c|c|c|}
\hline & \multicolumn{2}{|c|}{$\begin{array}{l}\text { Rank among African } \\
\text { exports destinations }\end{array}$} & \multicolumn{2}{|c|}{$\begin{array}{c}\text { Share in African } \\
\text { exports (\%) }\end{array}$} & \multicolumn{2}{|c|}{$\begin{array}{l}\text { Share in world } \\
\text { exports (\%) }\end{array}$} \\
\hline & $\begin{array}{c}2005- \\
2007 \\
\end{array}$ & $\begin{array}{c}2016- \\
2018 \\
\end{array}$ & $\begin{array}{r}2005- \\
2007\end{array}$ & $\begin{array}{r}2016- \\
2018 \\
\end{array}$ & $\begin{array}{r}2005- \\
2007\end{array}$ & $\begin{array}{l}2016- \\
2018 \\
\end{array}$ \\
\hline Netherlands & 2 & 1 & 8.2 & 8.8 & 4.2 & 4.2 \\
\hline France & 3 & 2 & 7.3 & 6.1 & 4.8 & 3.8 \\
\hline USA & 5 & 3 & 4.9 & 5.2 & 9.1 & 9.1 \\
\hline Germany & 4 & 4 & 6.0 & 5.0 & 7.9 & 6.3 \\
\hline China & 7 & 5 & 3.4 & 4.7 & 3.8 & 8.1 \\
\hline United Kingdom & 1 & 6 & 9.0 & 4.3 & 6.3 & 4.1 \\
\hline India & 14 & 7 & 1.9 & 4.3 & 0.8 & 1.7 \\
\hline Belgium & 8 & 8 & 3.3 & 3.2 & 3.3 & 2.6 \\
\hline Spain & 9 & 9 & 2.9 & 2.9 & 3.0 & 2.2 \\
\hline Russian Federation & 10 & 10 & 2.3 & 2.8 & 2.7 & 1.8 \\
\hline Saudi Arabia & 12 & 11 & 2.2 & 2.5 & 1.2 & 1.2 \\
\hline Viet Nam & 69 & 12 & 0.3 & 2.5 & 0.4 & 1.8 \\
\hline Italy & 6 & 13 & 3.7 & 2.2 & 4.5 & 3.0 \\
\hline United Arab Emirates & 22 & 14 & 1.0 & 2.0 & 0.8 & 1.1 \\
\hline South Africa & 11 & 15 & 2.3 & 1.7 & 0.5 & 0.4 \\
\hline Turkey & 17 & 16 & 1.2 & 1.6 & 0.7 & 1.0 \\
\hline Malaysia & 25 & 17 & 0.8 & 1.4 & 0.8 & 1.0 \\
\hline Japan & 13 & 18 & 2.1 & 1.4 & 5.3 & 3.9 \\
\hline Kenya & 24 & 19 & 0.8 & 1.4 & 0.1 & 0.2 \\
\hline Pakistan & 20 & 20 & 1.1 & 1.2 & 0.5 & 0.6 \\
\hline Total & & & 64.9 & 65.1 & 60.8 & 58.2 \\
\hline
\end{tabular}

Source: 2020 AATM database.

To sum up, with stagnating demand in OECD countries, Africa reoriented its exports to other markets. Yet African agricultural exports remain relatively low at the world level because of several bottlenecks that will be analyzed in Chapters 3 and 4 . 


\section{What do African countries trade?}

Table 2.2 presents the 20 most exported products in ascending order of their ranks in 2016-2018 along with their ranks in 2005-2007 and their shares in total agricultural exports in both periods. Cocoa beans, cashew nuts (in shell), tobacco, coffee, and oranges are the top five products, which together account for 27 percent of African agricultural exports in 2016-2018, on average. Cashew nuts ranked fifteenth in 2005-2007 but rose to second in 2016-2018. In contrast, coffee (not roasted or decaffeinated) lost its place to tobacco. Cocoa beans and oranges maintained their positions in both rankings as the first and fifth export products.

The top 10 export products represent 39 percent of Africa's agricultural exports and include cotton, sesame seeds, black tea, cocoa paste, and fresh grapes, in addition to the above-cited five products. Cotton ranked second in 2005-2007 but fell to sixth in 2016-2018. Sesame seeds progressed in the rankings from number 13 to 7 .

Table 2.2 List of the 20 most exported products from Africa in 2005-2007 and 2016-2018

\begin{tabular}{|c|c|c|c|c|c|}
\hline \multirow{3}{*}{$\begin{array}{l}\text { HS6 } \\
\text { Code }\end{array}$} & \multirow[b]{3}{*}{ Short Description } & \multirow{2}{*}{\multicolumn{2}{|c|}{$\begin{array}{c}\text { 2005-2007 } \\
\text { ExportShare }\end{array}$}} & \multicolumn{2}{|c|}{ 2016-2018 } \\
\hline & & & & \multicolumn{2}{|c|}{ Export Share } \\
\hline & & $(\%)$ & Rank & $(\%)$ & Rank \\
\hline 180100 & Cocoa beans & 12.5 & 1 & 12.1 & 1 \\
\hline 080131 & Cashew nuts, in shell & 1.3 & 15 & 4.2 & 2 \\
\hline 240120 & Tobacco, stemmed or stripped & 3.5 & 4 & 4.0 & 3 \\
\hline 090111 & Coffee, not roasted or decaffeinated & 4.2 & 3 & 3.4 & 4 \\
\hline 080510 & Oranges, fresh or dried & 3.4 & 5 & 3.2 & 5 \\
\hline 520100 & Cotton, not carded or combed & 6.3 & 2 & 2.9 & 6 \\
\hline 120740 & Sesamum seeds & 1.5 & 13 & 2.8 & 7 \\
\hline 090240 & Tea, black and (partly) fermented & 2.0 & 7 & 2.6 & 8 \\
\hline 180310 & Cocoa paste, not defatted & 1.5 & 12 & 2.0 & 9 \\
\hline 080610 & Grapes, fresh & 2.3 & 6 & 1.9 & 10 \\
\hline 170199 & Sucrose, no flavoring or coloring & 0.8 & 24 & 1.8 & 11 \\
\hline 070200 & Tomatoes, fresh or chilled & 1.1 & 19 & 1.6 & 12 \\
\hline 180400 & Cocoa butter, fat and oil & 1.3 & 14 & 1.6 & 13 \\
\hline 080520 & Mandarins, fresh or dried & 1.2 & 17 & 1.4 & 14 \\
\hline 090510 & Vanilla, neither crushed nor ground & 0.1 & 136 & 1.4 & 15 \\
\hline 060311 & Flowers, for bouquets & 0.4 & 45 & 1.4 & 16 \\
\hline 080390 & Bananas, other than plantains & 0.7 & 26 & 1.3 & 17 \\
\hline 150910 & Olive oil, virgin & 1.7 & 11 & 0.9 & 18 \\
\hline 170114 & Cane sugar, raw & 1.8 & 9 & 0.9 & 19 \\
\hline \multirow[t]{2}{*}{220421} & Wine, still & 1.9 & 8 & 0.9 & 20 \\
\hline & Total & 49.3 & & 52.6 & \\
\hline
\end{tabular}

Source: 2020 AATM database.

The top 20 products in 2016-2018 make up 53 percent of Africa's agricultural exports. The most noticeable progress in terms of export shares is achieved by cashew nuts (in shell), sesame seeds, 
vanilla, flowers, and sucrose, which ranked 15, 13, 136, 45, and 24, respectively, in 2005-2007 and are found among the top 20 export products in 2016-2018, ranking 2, 7, 15, 16, and 11, respectively. These products increased their shares, while the shares fell for other exports, including cotton, coffee, olive oil, raw cane sugar, and still wine. In a nutshell, Africa's exports remain concentrated in terms of both destination and products. Among the reasons behind the lack of diversification, trade policy is at the top of the list. The next section analyzes both tariff and nontariff measures and highlights how they affect African exports.

\section{Overview of trade protection faced by African agriculture}

\section{Tariffs}

The tariff regimes applied by African countries and those that their exporters face on world markets reveal that much remains to be achieved on the two fronts for further opening Africa's agriculture sector and enhancing Africa's access to world agricultural markets. Table 2.3 summarizes a comprehensive study by Bouët, Cosnard, and Laborde (2017) that estimates the average advalorem equivalent of tariffs levied on imports into African countries and those faced by African exporters on world markets. The table shows the frequency of African countries in specific ranges of average duty rates distinguishing duties levied and those faced, considering firstly whole economies and secondly national agriculture.

Table 2.3 Frequency of African countries by a range of average duty rate faced as exporters vs. levied as importers (\%)

\begin{tabular}{l|cc|c|c}
\hline \multirow{2}{*}{ Range of average duty rate (\%) } & \multicolumn{2}{|c|}{ Duty faced on export markets } & \multicolumn{2}{c}{ Duty levied on imports } \\
\cline { 2 - 5 } & All goods & Agricultural products & All goods & Agricultural products \\
\hline $0-5$ & 60 & 24 & 28 & 6 \\
$5-10$ & 35 & 36 & 35 & 18 \\
$10-20$ & 5 & 38 & 35 & 52 \\
$>20$ & 0 & 2 & 2 & 24 \\
\hline Total & 100 & 100 & 100 & 100 \\
\hline
\end{tabular}

Source: Authors, based on Bouët, Cosnard, and Laborde (2017, 10, Table 2.3).

It appears that 60 percent of African economies face average duty rates across all goods that are not higher than 5 percent. Only 5 percent of African economies face average duties that are higher than 10 percent. These include Kenya, Malawi, and Western Sahara, whose exports to world markets face, on average, ad-valorem equivalent duty rates of 12 percent, 13 percent, and 16 percent, respectively. However, African economies are more protected. Only 28 percent of those economies apply import tariffs not higher than 5 percent, while 37 percent of the economies impose average duty rates higher than 10 percent, including Djibouti whose import duty rates are 22 percent, on average.

With regard to agriculture, the same situation prevails. Table 2.3 reveals a divergence between Africa's access to world agricultural markets and the protection of national agricultures across 
the continent. About 52 percent of African countries impose average duty rates between 10 and 20 percent on agricultural imports from world markets and another 24 percent of countries apply average duty rates higher than 20 percent. In other words, 76 percent of African countries impose average duty rates higher than 10 percent. In contrast, only 40 percent of African countries face average duty rates higher than 10 percent in exporting to world agricultural markets, including 38 percent facing average rates between 10 and 20 percent. One can conclude from this that African agriculture is more protected from foreign competition than it is impeded by tariff barriers elsewhere.

To further illustrate the discrepancy, Tables 2.4 and 2.5 present the weighted average tariff rates levied as of 2018 on Africa's top agricultural imports from world markets and those faced by the continent's top exports to world markets. Table 2.4 shows that the cluster of top 20 import products, which accounts for 56.5 percent of Africa's agricultural imports in 2018 , faces a weighted average tariff rate as high as 10.8 percent. Nine of these products are protected by tariff rates higher than 10 percent while only maize is taxed at less than 5 percent. Milled rice is taxed at 8.9 percent, broken rice at 12.1 percent, and wheat and meslin at 7.1 percent, while other cereals are taxed at 10.8 percent. Even higher tariff rates are levied on palm oil and sugars, and food preparations and frozen meat and offal of fowls are the most protected among the top 20 import products, with average tariff rates at 43.3 percent and 21.1 percent, respectively.

Table 2.4 Effectively applied tariff rates levied on Africa's top 20 agricultural imports, 2018

\begin{tabular}{l|l|cc}
\hline $\begin{array}{l}\text { Product } \\
\text { HS-6 code }\end{array}$ & Product name & $\begin{array}{c}\text { Weighted } \\
\text { average } \\
\text { tariff rates (\%) }\end{array}$ & $\begin{array}{c}\text { Share in Africa's } \\
\text { agricultural } \\
\text { imports (\%) }\end{array}$ \\
\hline 100119 & Durum wheat, other than seed & 6.3 & 7.0 \\
100199 & Cereals, other than durum wheat, other than seed & 10.8 & 6.2 \\
100630 & Rice, semi-milled or wholly milled & 8.9 & 5.8 \\
100590 & Maize (corn), other than seed & 2.4 & 5.4 \\
151190 & Palm oil and its fractions, other than crude & 15.0 & 4.6 \\
170114 & Cane sugar, raw, in solid form & 15.4 & 3.4 \\
170199 & Sucrose, chemically pure, in solid form & 16.3 & 3.0 \\
151110 & Palm oil and its fractions, crude, not chemically modified & 10.2 & 2.2 \\
040221 & Milk and cream, concentrated, not containing sugar & 5.5 & 2.1 \\
210690 & Food preparations & 43.3 & 2.0 \\
020230 & Meat, of bovine animals, boneless cuts, frozen & 5.0 & 2.0 \\
150710 & Soya-bean oil, crude, not chemically modified & 5.6 & 2.0 \\
230400 & Oilcake and other solid residues of soya-bean & 4.8 & 1.9 \\
100640 & Rice, broken & 12.1 & 1.7 \\
020714 & Meat and edible offal, of fowls, frozen & 21.1 & 1.5 \\
110100 & Wheat or meslin flour & 7.4 & 1.3 \\
040210 & Milk and cream, concentrated or containing sugar & 7.3 & 1.2 \\
190190 & Food preparations, of flour, meal, starch, malt or milk & 10.7 & 1.2 \\
230990 & Dog or cat food & 5.1 & 1.2 \\
151211 & Sunflower seed or safflower oil and their fractions & 2.7 & 1.0 \\
\hline & Total top 20 agricultural imports & 10.8 & 56.5 \\
\hline
\end{tabular}

Source: World Integrated Trade Solution (WITS) database and authors' calculations. 
In contrast, Table 2.5 reveals that the cluster of top 20 export products, which represents 58 percent of Africa's agricultural exports, faces an average tariff rate of only 3.1 percent on world markets. Only three products in this cluster face an average tariff rate higher than 10 percent, including cashew nuts (in shell), sesame seeds, and maize (other than seed), whose export destinations are protected with average tariff rates of 11.1 percent, 12.3 percent, and 17.7 percent, respectively. Ten other products face tariff protection of less than 1 percent in world export markets, including cocoa beans, which account for 14.9 percent of African exports and face an average tariff rate of only 0.5 percent in world markets. The remaining products in this cluster face average tariff rates that are lower than 5 percent, except for tobacco (stemmed or stripped), which is taxed on average at 6.1 percent in world export markets.

Table 2.5 Effectively applied tariff rates faced by Africa's top 20 agricultural exports, 2018

\begin{tabular}{|c|c|c|c|}
\hline $\begin{array}{l}\text { Product HS-6 } \\
\text { code }\end{array}$ & Product name & $\begin{array}{l}\text { Weighted } \\
\text { average } \\
\text { tariff rates } \\
(\%)\end{array}$ & $\begin{array}{l}\text { Share in Africa's } \\
\text { agricultural } \\
\text { exports } \\
(\%)\end{array}$ \\
\hline 180100 & Cocoa beans & 0.5 & 14.9 \\
\hline 240120 & Tobacco, stemmed or stripped & 6.1 & 4.5 \\
\hline 090111 & Coffee, not roasted or decaffeinated & 2.5 & 3.8 \\
\hline 080510 & Oranges, fresh or dried & 4.3 & 3.6 \\
\hline 080610 & Grapes, fresh & 0.6 & 2.8 \\
\hline 090240 & Tea, black and (partly) fermented & 4.4 & 2.6 \\
\hline 180400 & Cocoa butter, fat and oil & 0.3 & 2.5 \\
\hline 080131 & Cashew nuts, in shell & 11.2 & 2.5 \\
\hline 180310 & Cocoa paste, not defatted & 0.7 & 2.4 \\
\hline 070200 & Tomatoes, fresh or chilled & 3.9 & 2.3 \\
\hline 090510 & Vanilla, neither crushed nor ground & 0.4 & 2.1 \\
\hline 080390 & Bananas, other than plantains & 0.2 & 2.0 \\
\hline 120740 & Sesamum seeds & 12.3 & 2.0 \\
\hline 060311 & Flowers, for bouquets & 0.4 & 2.0 \\
\hline 520100 & Cotton, not carded or combed & 1.7 & 1.8 \\
\hline 150910 & Olive oil, virgin & 0.8 & 1.7 \\
\hline 070820 & Beans, shelled or unshelled, fresh or chilled & 0.0 & 1.4 \\
\hline 220421 & Wine, still & 1.7 & 1.1 \\
\hline 100590 & Maize (corn), other than seed & 17.7 & 1.1 \\
\hline \multirow[t]{2}{*}{080440} & Avocados, fresh or dried & 0.4 & 1.0 \\
\hline & Total top 20 agricultural exports & 3.1 & 58.0 \\
\hline
\end{tabular}

Source: World Integrated Trade Solution (WITS) database and authors' calculations.

In sum, African countries are more protected against agricultural imports than the world markets are against their agricultural exports. While trade liberalization in developed countries remains crucial for expanding African agricultural exports, the implementation of the African Continental Free Trade Area is also expected to contribute to that expansion by dismantling or reducing tariff barriers between African countries themselves and between them and their emerging trading partners. 


\section{Frequency and coverage of nontariff measures}

In addition to tariffs, African exports are hindered by several NTMs. According to UNCTAD, NTMs are generally defined "as policy measures other than ordinary customs tariffs that can potentially have an economic effect on international trade in goods, changing quantities traded, or prices or both." Moreover, NTMs are heterogeneous and have different advantages and disadvantages. While the development of multilateral trade negotiations reduced tariff barriers, the use of NTMs as an instrument for trade regulation and consumer safety protection has increased over the past decades (WTO 2012).

In terms of heterogeneity, UNCTAD identifies 16 chapters of NTMs that include sanitary and phytosanitary measures (SPS), technical barriers to trade (TBT), price-control measures, quantitycontrol measures, and export-related measures. ${ }^{2}$ Among these measures, and in particular for agricultural products, domestic support in other countries and the resulting unfair competition with regards to the supported vs. the unsupported product affects the competitiveness of African countries' exports.

There are some arguments to justify the use of NTMs by different governments. First, generally speaking, as NTMs include contingent trade-protective measures, some arguments in favor of protectionism are relevant for NTMs (e.g. protection against unfair competition). Second, in some cases, while the increase of tariffs can be prohibited by the GATT/WTO rules thanks to bound duties, some NTMs are not prohibited. Third, NTMs can be imposed to protect human, animal, or plant life or health (such as the SPS or TBT measures). Finally, they might be employed to assist firms and workers who may be negatively affected by imports.

However, NTMs also may have several disadvantages. First, like tariffs, they induce a distortion in the market as they reduce competition and hence both prices and quantities deviate from those of the market equilibrium. Second, and as consequence of this, consumers will have a narrower choice of goods, with lower quality and higher prices (Maertens and Swinnen 2009). Third, when compared to tariffs, NTMs are less transparent since they include a wide range of standards not just an official rate consolidated at the WTO. Fourth, NTMs can be considered as a strategic barrier that comprises political and retaliatory components (Gawande 1997). Yet, it is important to note that, while NTMs can impede trade in some cases (which is why they are sometimes called nontariff barriers), they can boost trade when a country complies with specific standards or when these standards are harmonized (this is why, in this case, we refer to nontariff measures).

In general, the literature has shown that the negative effects of NTMs are likely to outweigh the positive effects in terms of trade, employment, and economic growth. Disdier et al. (2008) argued that African, Caribbean, and Pacific (ACP) countries' exports appear to have been negatively affected by SPS measures, whereas the impact on Asian countries was not statistically significant. In the same vein, Ghodsi et al. (2017) showed that the greatest trade-reducing effects are reported for SPS measures that have been imposed by the rest of the world on sub-Saharan Africa. Therefore, in our analysis, we will mainly focus on NTMs that are imposed on African exports given that the exporters are negatively affected by these measures, especially those imposed by

\footnotetext{
1 https://unctad.org/en/Pages/DITC/Trade-Analysis/Non-Tariff-Measures/NTMs-Classification.aspx

2 UNCTAD identifies 16 chapters of NTMs as follows: Chapter A: Sanitary and phytosanitary measures; Chapter B: Technical barriers to trade; Chapter C: Pre-shipment inspection and other formalities; Chapter D: Contingent trade-protective measures; Chapter E: Nonautomatic import licensing, quotas, prohibitions, quantity-control measures and other restrictions not including sanitary and phytosanitary measures or measures relating to technical barriers to trade; Chapter F: Price-control measures, including additional taxes and charges; Chapter G: Finance measures; Chapter H: Measures affecting competition; Chapter I: Trade-related investment measures; Chapter J: Distribution restrictions; Chapter K: Restrictions on post-sales services; Chapter L: Subsidies and other forms of support; Chapter M: Government procurement restrictions; Chapter N: Intellectual property; Chapter O: Rules of origin; and Chapter P: Export-related measures.
} 
the EU, which is a key trade partner for Africa. While this section analyzes NTMs in Africa and its main trade partners, Chapter 3 focuses on NTMs that affect intraregional African trade.

Table 2.6 shows that almost 50 percent of trade in agriculture is affected by one or more NTMs. ${ }^{3}$ These figures range from, on average, 29 percent for Gambia to 71 percent for Ghana. At the sectoral level, while on average 38 percent of trade in food products is affected by NTMs, this share reaches 49 percent for vegetables and 61 percent for the animal sector. These shares can be as high as 95 percent for animals in Ethiopia, and 63 percent for food products in Ghana and 79 percent for vegetables in Ghana as well. This shows the extent to which NTMs hinder a significant share of trade in agriculture. As a consequence of these NTMs, prices of African exports are likely to increase. Indeed, Andriamananjara et al. (2004) showed that, for instance, NTMs on vegetable oils and fats increased their prices significantly.

It is important to compare Africa to other large producers of agricultural products such as Brazil, China, India, the EU, and the United States. A significant share of trade of these countries is subject to one or more NTMs. The highest share is that of the United States (81 percent for food products), followed by Brazil (83 percent for vegetables, 75 percent for food, and 74 percent for animal products), and the EU (55 percent for vegetables, 46 percent for animals, and 43 percent for food products). India's share of trade affected by one or more NTMs is lower than other countries' (ranging from 23 percent for food products to 47 percent for vegetables). ${ }^{4}$

Table 2.6 Share of trade affected by NTMs

\begin{tabular}{l|ccc}
\hline & Animals & Food products & Vegetables \\
\hline Algeria & $55 \%$ & $41 \%$ & $74 \%$ \\
Benin & $73 \%$ & $49 \%$ & $47 \%$ \\
Burkina Faso & $53 \%$ & $42 \%$ & $62 \%$ \\
Côte d'Ivoire & $37 \%$ & $42 \%$ & $31 \%$ \\
Cameroon & $74 \%$ & $55 \%$ & $39 \%$ \\
Ethiopia & $95 \%$ & $57 \%$ & $42 \%$ \\
Ghana & $71 \%$ & $63 \%$ & $79 \%$ \\
Gambia & $36 \%$ & $16 \%$ & $32 \%$ \\
Liberia & $60 \%$ & $47 \%$ & $59 \%$ \\
Morocco & $62 \%$ & $29 \%$ & $57 \%$ \\
Mauritania & $50 \%$ & $14 \%$ & $48 \%$ \\
Niger & $70 \%$ & $40 \%$ & $63 \%$ \\
Nigeria & $70 \%$ & $36 \%$ & $33 \%$ \\
Senegal & $62 \%$ & $6 \%$ & $43 \%$ \\
Tunisia & $55 \%$ & $29 \%$ & $29 \%$ \\
\hline Brazil & $74 \%$ & $75 \%$ & $83 \%$ \\
European Union & $46 \%$ & $43 \%$ & $55 \%$ \\
India & $40 \%$ & $23 \%$ & $47 \%$ \\
USA & $74 \%$ & $81 \%$ & $67 \%$ \\
\hline Saure: & & &
\end{tabular}

Source: UNCTAD dataset.

Note: (i) Sum of gross imports or gross exports that are affected by one or more NTMs.

(ii) These figures come from the latest available year for each country (see Appendix Table A2.1).

3 The UNCTAD dataset does not include all African countries. This is why we report countries for data is available.

4 Even though China is interesting to take into consideration, we were not able to find data. 
A closer look at NTMs shows that some of these measures can be more trade-impeding than others. Table 2.7 presents the coverage ratio that is calculated by determining the value of trade of each commodity subject to NTMs in the value of total trade, the frequency ratio that indicates the percentage of traded products to which one or more NTMs are applied, and the count of traded HS 6-digit products that are subject to one or more NTM measures. ${ }^{5}$ These indices show the incidence of NTMs, not their impact. The latter needs to be assessed through another methodology, including gravity models and simulations. It is notable that, in terms of the number of products affected by NTMs, the vegetable sector ranks first. Moreover, for the EU, the United States, and Brazil, the number of products affected by NTMs is generally higher than for African countries. Indeed, the mounting and more stringent NTMs may challenge exports of African countries, especially measures related to product quality and health safety (Santeramo and Lamonaca 2019). For instance, according to Kalaba and Kirsten (2012), for the Southern African Development Community (SADC), most of the SPS measures are imposed on fruits (that can carry insects or pesticides), meat and dairy products (that can contain bacteria such as salmonella and listeria), and livestock (to limit the spread of various diseases). Clearly such measures can be required for safety reasons. Yet, some other NTMs that are less technical and that are related to prices or quantities are more likely to exert a negative effect on trade.

Table 2.7 Share of trade affected by one or more NTMs

\begin{tabular}{l|ccc|ccc|ccc}
\hline & \multicolumn{3}{|c|}{ Animals } & \multicolumn{3}{c}{ Vegetables } & \multicolumn{3}{c}{ Food Products } \\
& Cov. & Freq. & Num. & Cov. & Freq. & Num. & Cov. & Freq. & Num. \\
\hline Algeria & 56 & 52 & 108 & 42 & 50 & 227 & 76 & 73 & 94 \\
Benin & 74 & 65 & 69 & 48 & 50 & 81 & 51 & 47 & 75 \\
Burkina Faso & 55 & 45 & 43 & 40 & 41 & 100 & 60 & 53 & 63 \\
Côte d'Ivoire & 36 & 34 & 59 & 26 & 19 & 43 & 32 & 16 & 34 \\
Cameroon & 76 & 72 & 110 & 44 & 20 & 88 & 43 & 37 & 36 \\
Ethiopia & 80 & 80 & 107 & 57 & 48 & 117 & 41 & 40 & 84 \\
Ghana & 71 & 64 & 120 & 54 & 55 & 200 & 77 & 72 & 101 \\
Gambia & 36 & 51 & 46 & 15 & 29 & 50 & 30 & 28 & 41 \\
Liberia & 64 & 60 & 85 & 46 & 53 & 118 & 58 & 53 & 84 \\
Morocco & 59 & 57 & 108 & 28 & 39 & 154 & 57 & 51 & 74 \\
Mauritania & 42 & 52 & 64 & 13 & 16 & 122 & 48 & 49 & 26 \\
Niger & 65 & 50 & 59 & 38 & 28 & 149 & 63 & 62 & 49 \\
Nigeria & 61 & 58 & 73 & 36 & 46 & 129 & 31 & 49 & 84 \\
Senegal & 53 & 48 & 63 & 6 & 8 & 77 & 42 & 31 & 14 \\
Tunisia & 56 & 58 & 98 & 31 & 33 & 73 & 31 & 29 & 55 \\
\hline Brazil & 55 & 77 & 250 & 65 & 64 & 226 & 81 & 77 & 162 \\
European Union & 45 & 45 & 146 & 55 & 52 & 182 & 44 & 43 & 90 \\
India & 40 & 44 & 48 & 48 & 38 & 96 & 32 & 38 & 71 \\
USA & 50 & 51 & 91 & 80 & 74 & 225 & 54 & 53 & 98
\end{tabular}

Source: UNCTAD dataset.

Note: (i) Cov. represents the coverage ratio that is calculated by determining the value of trade of each commodity subject to NTMs, aggregating by applicable HS commodity group, and expressing the value of trade covered as a percentage of total trade in the HS commodity group. (ii) Freq. represents the frequency ratio accounts for the presence or absence of an NTM, and indicates the percentage of traded products to which one or more NTMs are applied. (iii) Num. represents the count of traded HS 6 digits products that are subject to one or more NTM measures. (iv) These figures come from the latest available year for each country (see Appendix Table A2.1).

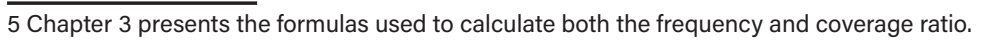


Figures 2.6, 2.7, and 2.8 confirm these findings. They show the share of products subject to zero NTMs, one or two types of NTMs, and three or more NTMs. While, on average 20 percent of vegetable and food products are not subject to NTMs, this share increases to 40 percent for the animal sector. By contrast, several countries have substantial shares of products facing three or more types of NTMs - Ethiopia, Benin, Ghana, Morocco, and Tunisia for vegetable exports (not less than 60 percent), animal exports (almost 50 percent), and food product exports (not less than 60 percent). Vegetables with one or two NTMs represent more than 70 percent for Algeria, Côte d'Ivoire, Cameroon, Niger, Nigeria, and Senegal. These figures are slightly lower for food products and even lower for animals.

Figure 2.6 Number of NTMs by product and country, vegetable sector

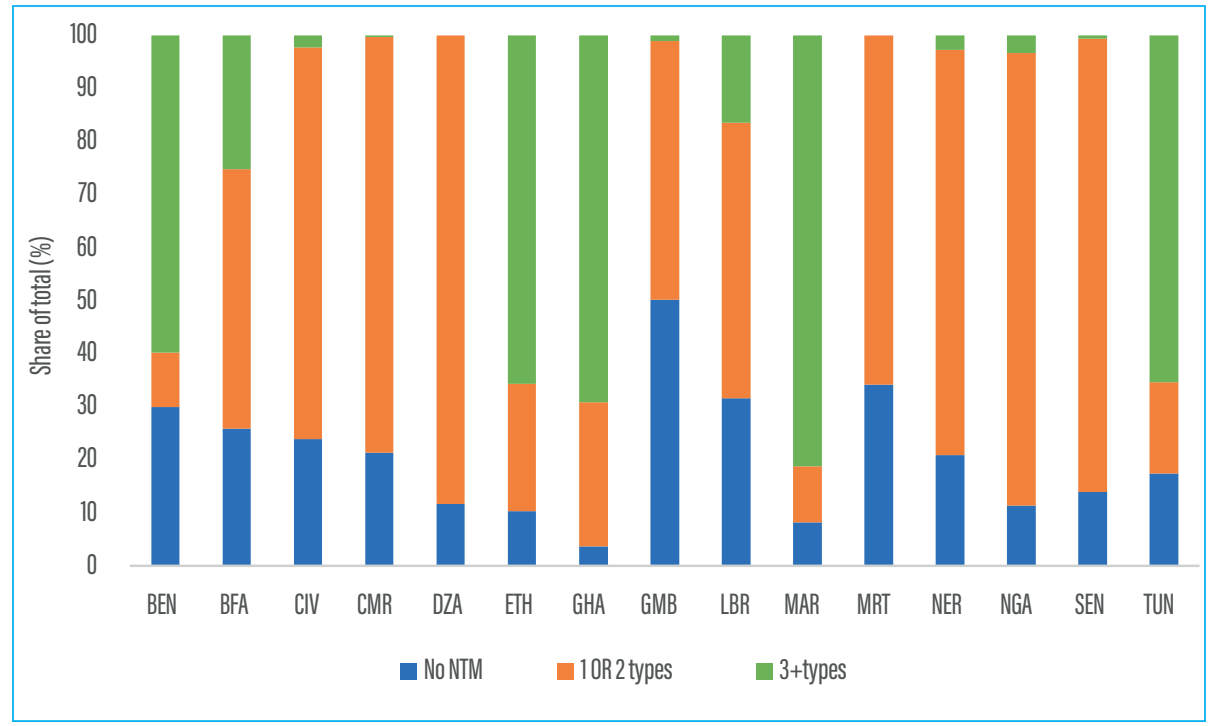

Source: Authors' elaboration using the UNCTAD dataset.

Note: These figures come from the latest available year for each country (see Appendix Table A2.1).

Figure 2.7 Number of NTMs by product and country, animal sector

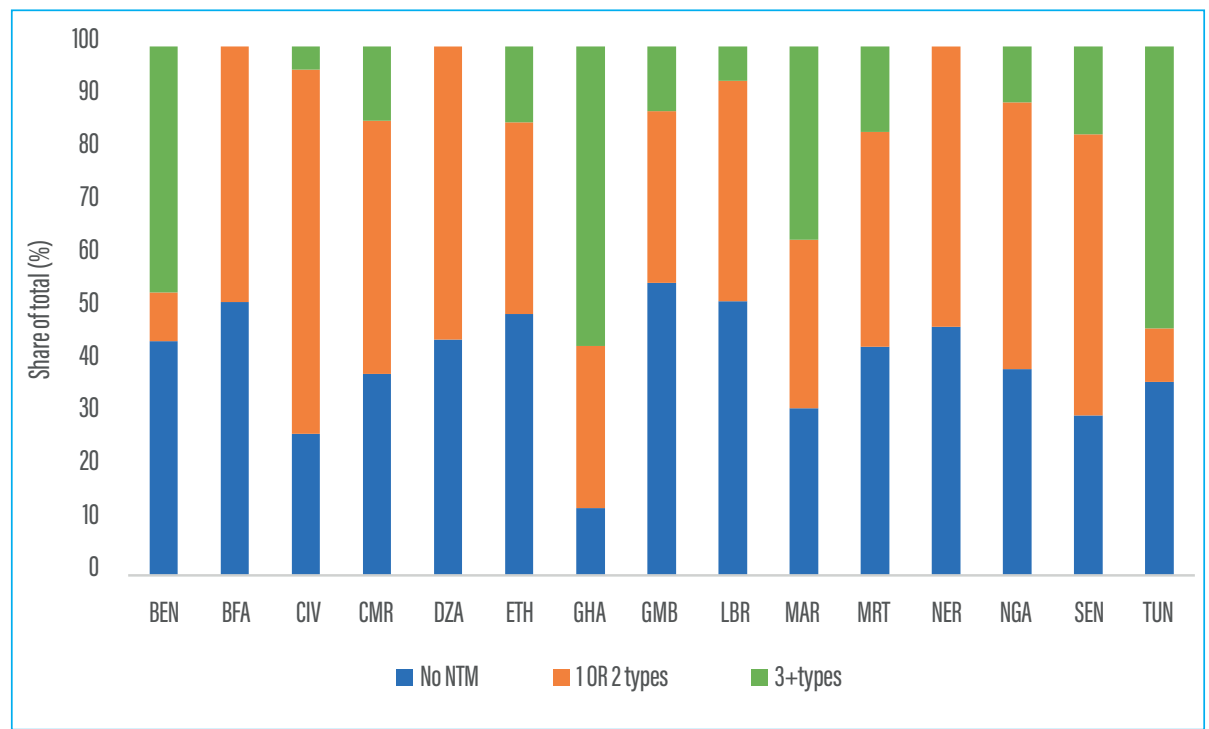

Source: Authors' elaboration using the UNCTAD dataset.

Note: These figures come from the latest available year for each country (see Appendix Table A2.1). 
Figure 2.8 Number of NTMs by product and country, food products sector

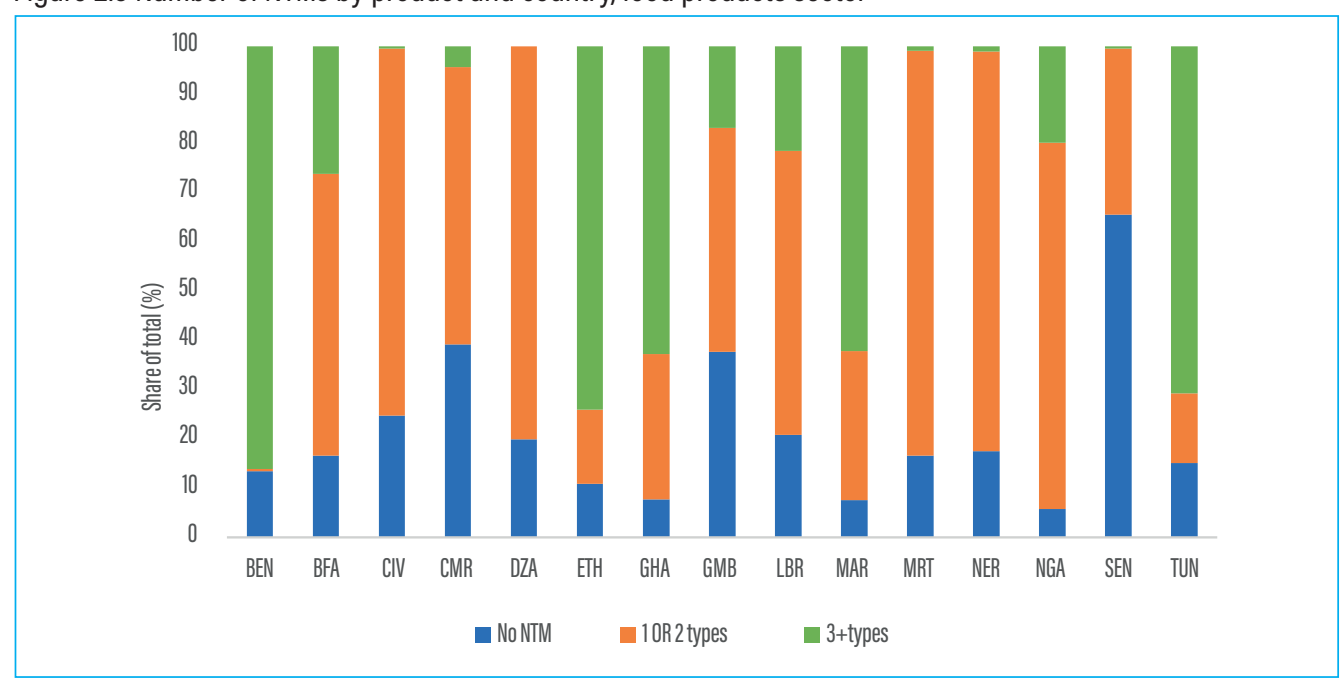

Source: Authors' elaboration using the UNCTAD dataset.

Note: These figures come from the latest available year for each country (see Appendix A2.1).

In summary, exports of African agricultural products face numerous NTMs that reduce their competitiveness at the world level. The next section examines the types of NTMs that affect African exporters most.

\section{Types of NTMs}

Table 2.8 presents the main types of NTMs that affect agricultural products, namely SPS measures and export-related measures (primarily domestic support). We focus on these NTMs for two reasons. First, SPS measures deal mainly with the protection of human or animal life from risks arising from additives, contaminants, and toxins in their food. Therefore, they are mainly imposed on agricultural products. Furthermore, several countries that are large producers of agricultural products tend to protect this sector through domestic support (mainly the EU, United States, and China). Second, in terms of impact, as it will be shown later, these measures affect the competitiveness of African products and thus reduce their market access in the main importing

First, while SPS measures represent, on average, 53 percent of the total number of measures, export-related measures ${ }^{6}$ represent 20 percent and other measures 27 percent. Second, for most of the countries in the case of SPS, the coverage ratio is greater than the frequency ratio, showing how a large share of the value of trade is subject to NTMs. In addition, SPS measures affect a higher number of products than the other types of measures since, on average, 107 products are affected by SPS while 42 and 56 products respectively are affected by export-related and other measures. This prevalence of SPS measures is particularly high in Ethiopia (117 products), Morocco (118), Liberia (130), Niger (139), Nigeria (149), and Ghana (183). Export-related measures are especially prevalent for exports from Ethiopia (67 products), Tunisia (72), Morocco (96), and Ghana (115).

The other producers of agricultural products (Brazil, India, EU, and United States) have larger figures for the coverage ratio, frequency ratio, and the number of products subject to NTMs (with the exception of India). This indicates to what extent these countries are more stringent in terms of NTMs (especially SPS measures) when compared to African countries (see Table 2.8).

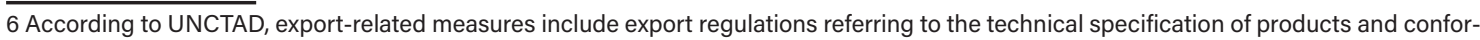
mity assessment systems thereof, export formalities; export licenses, export quotas, export prohibition and other restrictions other than sanitary and phytosanitary or technical barriers to trade measures; export price-control measures, including additional taxes and charges, state-trading enterprises, for exporting and other selective export channels; export-support measures; and measures on re-export. 
It is important also to note that some SPS measures can be more stringent and hence more costly than others. For instance, Otsuki and Sewadeh (2001) found a negative effect of the EU standard for aflatoxin on African exports. They showed that shifting from the Codex Alimentarius standard, (established by the Food and Agriculture Organization of the United Nations and the World Health Organization) to the more stringent European Commission standards decreases African exports of cereals, dried fruits, and nuts to Europe. This result has also been confirmed by El-Enbaby et al. (2016) and Ghodsi et al. (2017), who both found that standards and restrictions implemented in Europe and Central Asia affect imports more than do North American NTMs. Yet, some studies highlighted the potential positive effect of NTMs on exports. Indeed, Martens and Swinnen (2009) showed that exports increased significantly despite increasing standards, which contributed to rising rural incomes and poverty reduction. This positive impact reflects the fact that tightening standards led to a shift from smallholder contract farming to large estate production and thus boosted labor demand.

Table 2.8 Types of NTMs

\begin{tabular}{|c|c|c|c|c|c|c|c|c|c|c|c|c|}
\hline & \multicolumn{4}{|c|}{ SPS } & \multicolumn{4}{|c|}{ Export-related } & \multicolumn{4}{|c|}{ Other } \\
\hline & Cov. & Freq. & Num. & Share & Cov. & Freq. & Num. & Share & Cov. & Freq. & Num. & Share \\
\hline Benin & 55 & 53 & 82 & 52 & 66 & 67 & 53 & 17 & 66 & 60 & 97 & 31 \\
\hline Burkina Faso & 61 & 59 & 97 & 75 & 56 & 50 & 39 & 25 & 29 & 21 & 40 & 0 \\
\hline Côte d'Ivoire & 27 & 20 & 42 & 42 & 35 & 9 & 14 & 25 & 21 & 24 & 48 & 33 \\
\hline Cameroon & 52 & 52 & 122 & 47 & 67 & 37 & 37 & 37 & 28 & 28 & 56 & 16 \\
\hline Algeria & 63 & 66 & 156 & 73 & 0 & 0 & 0 & 0 & 40 & 33 & 79 & 27 \\
\hline Ethiopia & 56 & 56 & 117 & 50 & 72 & 62 & 67 & 17 & 59 & 41 & 88 & 33 \\
\hline Ghana & 82 & 80 & 183 & 32 & 81 & 64 & 115 & 16 & 24 & 23 & 52 & 52 \\
\hline Gambia & 39 & 46 & 62 & 51 & 14 & 27 & 13 & 7 & 10 & 16 & 21 & 41 \\
\hline Liberia & 71 & 67 & 130 & 55 & 51 & 76 & 33 & 10 & 27 & 27 & 51 & 35 \\
\hline Morocco & 45 & 49 & 118 & 56 & 60 & 54 & 96 & 22 & 45 & 38 & 102 & 22 \\
\hline Mauritania & 37 & 40 & 74 & 40 & 32 & 40 & 37 & 24 & 9 & 22 & 29 & 36 \\
\hline Niger & 78 & 75 & 139 & 70 & 37 & 13 & 5 & 30 & 35 & 24 & 53 & 0 \\
\hline Nigeria & 65 & 77 & 149 & 55 & 5 & 22 & 9 & 14 & 18 & 19 & 34 & 32 \\
\hline Senegal & 38 & 37 & 69 & 63 & 49 & 32 & 45 & 26 & 10 & 8 & 12 & 11 \\
\hline Tunisia & 37 & 35 & 71 & 46 & 50 & 47 & 72 & 23 & 31 & 38 & 80 & 31 \\
\hline Brazil & 100 & 99 & 224 & 27 & 97 & 99 & 216 & 5 & 42 & 39 & 93 & 68 \\
\hline EU & 97 & 95 & 283 & 32 & - & - & - & 2 & 34 & 33 & 97 & 66 \\
\hline India & 88 & 92 & 172 & 52 & 18 & 3 & 7 & 1 & 26 & 27 & 54 & 48 \\
\hline USA & 96 & 92 & 273 & 32 & 98 & 100 & 298 & 13 & 60 & 60 & 177 & 54 \\
\hline
\end{tabular}

Source: Authors' elaboration using the UNCTAD dataset.

Note: (i) Cov. represents the coverage ratio that is calculated by determining the value of trade of each commodity subject to NTMs, aggregating by applicable HS commodity group, and expressing the value of trade covered as a percentage of total imports in the HS commodity group.(ii) Freq. represents the frequency ratio accounts for the presence or absence of a NTM, and indicates the percentage of traded products to which one or more NTMs are applied. (iii) Num represents the count of traded HS 6-digit products that are subject to one or more NTM measures. (iv) Share represents the share of each measure in the total number of measures affecting each country. (v) Other includes: technical barriers to trade; preshipment inspection and other formalities; price control measures; licenses, quotas, prohibitions and other quantity control measures; charges, taxes and other para-tariff measures; finance measures and trade-related investment measures. 
Since NTMs are heterogeneous, they do not all have the same effect on African exporters. Using the International Trade Center surveys, Table 2.9 shows that most of African exporters perceive conformity assessment measures (that include control and approval procedures such as inspection, testing, certification, and traceability designed to safeguard consumer health and safety) create the greatest impediments to trade. Indeed, on average, when companies are asked to describe the type of regulatory obstacle to trade that they face, 36 percent of the barriers mentioned are related to conformity assessment followed by export-related measures (30 percent). At the country level, companies in Burkina Faso attribute 64.5 percent of the barriers to conformity assessment, followed by Mauritius ( 56.6 percent), Senegal (47.2 percent) and Guinea (31.6 percent). For exportrelated measures, the figures are particularly high for Tanzania (57.5 percent), Madagascar (53.1 percent), Malawi (50.5 percent), Kenya (39.2 percent), and Guinea (35.2 percent).

Table 2.9 NTMs faced by African exporters in the agriculture sector

\begin{tabular}{l|cccccc}
\hline & $\begin{array}{c}\text { Export- } \\
\text { related }\end{array}$ & $\begin{array}{c}\text { Conformity } \\
\text { assess. }\end{array}$ & $\begin{array}{c}\text { Technical } \\
\text { req. }\end{array}$ & $\begin{array}{c}\text { Rules of } \\
\text { origin }\end{array}$ & Others & Total \\
\hline Burkina Faso & 8.1 & 64.5 & 9.7 & 6.5 & 11.2 & 100 \\
Côte d'Ivoire & 28.4 & 30.2 & 0 & 13.6 & 27.8 & 100 \\
Egypt & 21.3 & 23.7 & 31 & 7.8 & 16.2 & 100 \\
Guinea & 35.2 & 31.6 & 5.5 & 0 & 27.7 & 100 \\
Kenya & 39.2 & 28.8 & 8.4 & 15.9 & 7.7 & 100 \\
Madagascar & 53.1 & 13 & 21.4 & 7.6 & 4.9 & 100 \\
Malawi & 50.5 & 32 & 6.2 & 0 & 11.3 & 100 \\
Mauritius & 13.3 & 56.6 & 18.1 & 0 & 12 & 100 \\
Morocco & 25.6 & 26.8 & 47.6 & 0 & 0 & 100 \\
Rwanda & 8.6 & 58 & 7.4 & 5.6 & 20.4 & 100 \\
Senegal & 23.4 & 47.2 & 21.8 & 0 & 7.6 & 100 \\
Tanzania & 57.5 & 19.2 & 8.2 & 13.7 & 1.4 & 100 \\
\hline Average & 30 & 36 & 15 & 6 & 13 & 100 \\
\hline
\end{tabular}

Source: International Trade Center.

Note: (i) These figures come from different surveys that were implemented between 2011 and 2013. (ii) Affected companies are asked to describe the type of regulatory obstacle to trade they face. These regulatory difficulties are categorized according to the NTM classification for surveys. (iii) Others include also pre-shipment.

Finally, it is important to examine the role of domestic support in countries that are large producers of agricultural products. If domestic support is concentrated in countries that can influence world agricultural markets, such support will be significantly distorting for small producers, like African countries. Indeed, data show that large agro-food producing countries that are heavily involved in international trade provide much of the world's domestic agricultural support. This, in turn, significantly increases world supply and decreases world prices.

Figure 2.9 shows the different components of domestic support (producer, consumer, and general service support) in two emerging economies (China and Brazil) and two developed ones (the EU and the United States). In general, while total support exhibits a declining trend in all destinations, on average, China's level remains the highest (2.1 percent of GDP) followed by the EU ( 0.9 percent), Brazil ( 0.6 percent), and the United States ( 0.5 percent). A more detailed analysis shows that this ranking differs for each component of domestic support. The EU appears to provide the highest support, amounting to 25 percent of gross farm receipts, followed by the United States (12 percent), 
China (11 percent), and Brazil (5 percent). The general services support measured as a percentage of total support provided in Brazil is the highest ( 30 percent), followed by China ( 25 percent), the EU (11 percent), and United States (10 percent). Consumer support exhibits a different pattern. Indeed, while several countries provide a subsidy for consumers, they also impose different taxes. This is why for Brazil, China, and the EU, the consumer support measured as a percentage of agricultural consumption has a negative value. The only country where subsidies are higher than taxes is the United States. At the product level, OECD countries provide support mainly to the rice, maize, pork, beef, and dairy sectors (in absolute terms).

Thus, each country has its own distorting tool that can affect African producers: Brazil is a large user of government support service, the EU-28 provides its support to producers, and the United States to its consumers. In general, as a matter of size and policy choice, China has the highest support as a share of GDP.

Figure 2.9 Domestic support in selected markets

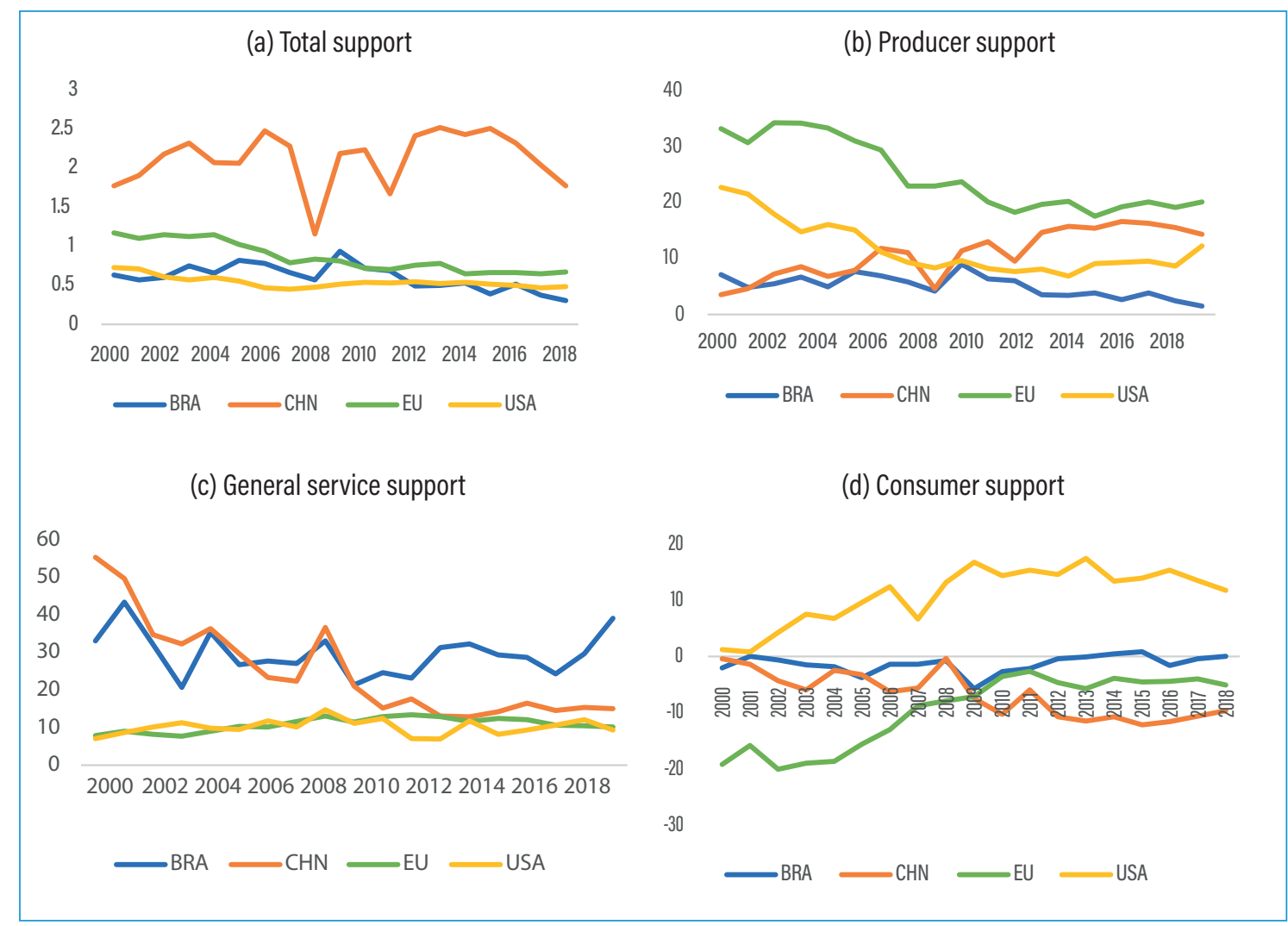

Source: OECD dataset.

Note: (i) BRA = Brazil, $\mathrm{CHN}=$ China, EU = European Union, USA = United States of America. (ii) The total support is measured as a percentage of GDP. Producer support is measured as a percentage of gross farm receipts. Consumer support is measured as a percentage of agricultural consumption. The general services support estimate (GSSE) is measured as a percentage of total support. (iii) Total support transfers represent the total support granted to the agricultural sector, and consist of producer support, consumer support, and general services support. (iv) Producer support transfers to agricultural producers are measured at the farmgate level and comprise market price support, budgetary payments, and the cost of revenue foregone. (v) Consumer support transfers from consumers of agricultural commodities are measured at the farmgate level. If negative, it measures the burden (implicit tax) on consumers through market price support (higher prices) that more than offsets consumer subsidies that lower prices to consumers. (vi) GSSE transfers are linked to measures creating enabling conditions for the primary agricultural sector through the development of private or public services, institutions, and infrastructure. GSSE includes policies where primary agriculture is the main beneficiary but does not include any payments to individual producers. GSSE transfers do not directly alter producer receipts or costs or consumption expenditure. 


\section{Conclusion}

Although Africa's share of world agricultural trade has remained low, the value of its exports has been growing steadily. African exporters are diversifying from EU market destinations to emerging markets of BRIC and elsewhere outside the developing world. This chapter sheds light on the EU's decreasing importance and the increasing weight BRIC and "other world regions" as destinations for Africa's agricultural exports. It reveals that countries including Viet Nam, India, and China are significantly displacing the United Kingdom, Italy, France, and Germany. Some emerging products such as cashew nuts (in shell), sesame seeds, vanilla, flowers, and sucrose are surpassing traditional products such cotton, coffee, olive oil, cane sugar, and wine in the ranking of top export products. Hence, African agricultural exports are being diversified in terms of both their destinations and products.

The chapter also investigates agriculture sector protection in and outside Africa. The tariff regimes applied by African countries and those faced by their exporters on world markets reveal that much remains to achieve on the two fronts of further opening Africa's agricultural sectors and enhancing Africa's access to world agricultural markets. While efforts of regional integration schemes are culminating in a wider continental free trade area, African governments will have to play a critical role in enforcing the removal of nontariff barriers to intracontinental trade. The challenge of further opening national agriculture sectors is crucial as intracontinental destinations account for 20 percent of Africa's agricultural exports.

In terms of nontariff measures, conformity assessment remains one of the most serious impediments affecting African exporters. Domestic support in both developed and emerging markets is also crucial since much of the support is provided by large agrifood producing countries that are heavily involved in international trade. Thus, from a policy perspective, adopting a more comprehensive approach to help African exporters increase their competitiveness is essential to reduce the negative effect of NTMs. Finally, it is worth noting that all these policies must be coupled with an improvement in customs efficiency. Indeed, the trade performance of African agriculture is also related to administrative barriers, lack of efficiency of African customs procedures, and lack of transportation and telecommunication infrastructure.

\section{References}

Andriamananjara, S., J. M. Dean, M. J. Ferrantino, R. M. Feinberg, R. D. Ludema, and M. E. Tsigas. 2004. "The Effects of Non-tariff Measures on Prices, Trade, and Welfare: CGE Implementation of Policy-based Price Comparisons. Trade, and Welfare: CGE Implementation of Policy-Based Price Comparisons." Working Paper 15863, US International Trade Commission, Office of Economics, Washington, DC.

Boniphace, N. S., N. Fengying, and F. Chen, 2015. "An Analysis of Smallholder Farmers' Socioeconomic Determinants for Inputs Use: A Case of Major Rice Producing Regions in Tanzania." Russian Journal of Agricultural and Socio-Economic Sciences 38 (2).

Bouët, A., L. Cosnard, and D. Laborde. 2017. "Measuring Trade Integration in Africa." Journal of Economic Integration 32 (4): 937-77. 
Disdier, A. C., L. Fontagné, and M. Mimouni. 2008. "The Impact of Regulations on Agricultural Trade: Evidence from the SPS and TBT Agreements." American Journal of Agricultural Economics 90 (2): 336-350.

El-Enbaby, H., R. Hendy, and C. Zaki. 2016. “Do SPS Measures Matter for Margins of Trade? Evidence from Firm-Level Data." Applied Economics 48 (21): 1949-1964.

Gawande, K. 1997. "A Test of a Theory of Strategically Retaliatory Trade Barriers." Southern Economic Journal 64 (2): 425-449.

Gelan, A., and A. Omore. 2014. "Beyond Tariffs: The Role of Non-Tariff Barriers in Dairy Trade in the East African Community Free Trade Area." Development Policy Review 32 (5): 523-543.

Ghodsi, M., J. Grübler, O. Reiter, and R. Stehrer. 2017. "The Evolution of Non-tariff Measures and their Diverse Effects on Trade." wiiw Research Report 419, wiiw, Vienna.

Kalaba, M., and J. Kirsten. 2012. "Estimating the Quantity Effects of Non-Tariffs Measures in SADC Meat and Milk Trade." Working Paper 206513, Department of Agricultural Economics, Extension and Rural Development, University of Pretoria, South Africa.

Liu, C., D. Lin, J. Liu, and Y. Li. 2019. "Quantifying the Effects of Non-tariff Measures on African Agrifood Exporters." Agrekon 58 (4): 451-471.

Maertens, M., and J. Swinnen. 2009 "Trade, Standards, and Poverty: Evidence from Senegal." World Development 37 (1): 161-178.

Moyo, S. 2016. "Family Farming in sub-Saharan Africa: Its Contribution to Agriculture, Food Security and Rural Development." Working Paper 150, FAO and the International Policy Centre for Inclusive Growth of the United Nations Development Program.

Olayide, O. E., I. K. Tetteh, and L. Popoola. 2016. "Differential Impacts of Rainfall and Irrigation on Agricultural Production in Nigeria: Any Lessons for Climate-Smart Agriculture?" Agricultural Water Management 178: 30-36.

Otsuki, T., J. S. Wilson, and M. Sewadeh. 2001. "What Price Precaution? European Harmonization of Aflatoxin Regulations and African Groundnut Exports." European Review of Agricultural Economics 28 (3): 263-284.

Pindiriri, C. 2018. "Breaking the Traditional Trap: Assessing Drivers of Modern Technology Adoption by Smallholder Farmers in Hurungwe District, Zimbabwe." In Building a Resilient and Sustainable Agriculture in Sub-Saharan Africa edited by A. Shimeles, A. Verdier-Chouchane, and A. Boly, 3353). Cham, Switzerland: Palgrave Macmillan.

Santeramo, F. G., and E. Lamonaca. 2019. "On the Impact of Non-tariff Measures on Trade Performances of the African Agri-food Sector." Agrekon 58 (4): 389-406.

World Bank. 2015. Africa's Pulse: An Analysis of Issues Shaping Africa's Economic Future, vol 11. Washington, DC. 


\section{References}

Table A2.1 NTMs reference year

\begin{tabular}{lc|c}
\hline Country & Code & Year \\
\hline Algeria & African Countries & \\
Benin & DZA & 2016 \\
Burkina Faso & BEN & 2014 \\
Cameroon & BFA & 2012 \\
Côte d'Ivoire & CMR & 2015 \\
Ethiopia & CIV & 2012 \\
Gambia, The & ETH & 2015 \\
Ghana & GMB & 2013 \\
Morocco & GHA & 2014 \\
Senegal & MAR & 2016 \\
Tunisia & SEN & 2012 \\
Liberia & TUN & 2016 \\
Mauritania & LBR & 2014 \\
Niger & MRT & 2015 \\
Nigeria & NER & 2014 \\
\hline & NGA & 2013 \\
\hline Brazil & BRA & 2016 \\
European Union & EUN & 2016 \\
India & IND & 2012 \\
United States & USA & 2014 \\
\hline Sorce & Non-African &
\end{tabular}

Source: UNCTAD, Chapter 3 (Intra-African Trade Integration). 
